effects of solar flares; and two relate to marine expeditions, one prospective and the other that of the Albatross, to obtain sediment cores to study the geochronology of the deep ocean bed.

\section{Institution of Mining and Metallurgy}

The second Sir Julius Wernher Memorial Lecture of the Institution of Mining and Metallurgy will be given by Dr. C. H. Desch, who will speak on "The Effect of Impurities on the Properties of Metals". The Lecture will be delivered at the Royal Institution, 21 Albemarle Street, London, W.1, on July 6, at 5 p.m., and admission is free and without ticket.

The Institution will be holding a symposium on "The Refining of Non-Ferrous Mietals" during July $7-8$ at the Royal Institution of Chartered Surveyors, 14 Great George Street, Westminster, London, S.W.1. Tickets of admission (which are free) and further information may be obtained from the Secretary, Institution of Mining and Metallurgy, Salisbury House, Finsbury Circus, London, E.C.2.

\section{Canadian Scholarship Awards}

SCHOLARSHAs have been granted by the National Research gouncil of Canada to 165 graduates to enable them to pursue postgraduate studies during the academic year 1949-50. There are nineteen fell wships at 900 dollars, sixty-four studentships at 700 dollars and seventy-eight bursaries at 450 dollars tenable at Canadian universities, and four special scholarships at 750 dollars awarded for study outside Canada. The nominal value of all scholarships for the year is 103,200 dollars as compared with the total for last year of 148 scholarships worth 97,050 dollars. Physics is represented by 65 , and chemistry, in its several branches, by 59 . The remainder are distributed in the other sciences as follows: bac. teriology, 1 ; biology, 4; communications engineer. ing, 1; cytogenetics, 1; electrical engineering, 2 ; geology, 3 ; histology, 2 ; mathematics, 3 ; medical research, 2; microwave studies, 1; metallurgy, 2; mineralogy, 2 ; nutrition, 1 ; physical metallurgy, 2 ; physiology, 1; radiation studies, 2 ; spectroscopy, 3 ; zoology, 8.

\section{Colonial Service: Recent Appointments}

THE following appointments in the Colonial Service have been announced: G. Swaine, entomologist, Tanganyika; R. L. Woolridge, veterinary officer, Kenya E. Pawson, agricultural chemist, Northern BXodesia; K. L. Richards, livestock officer, Africultural Department, Cyprus; A. J. Whitakch, electrical engineer, Nigeria ; J. L. King (depyly electrical engineer-in-chief, Nigeria), electrigal engineer-in-chief, Nigeria; J. M. Stock (senior electrical engineer, Nigeria), deputy electrical engineer-in-chief, Nigeria; J. R. Lockie (conservator of forests, Nigeria), assistant chief conservator of forests, Nigeria; R. Smeathers (assistant conservator of forests, Trinidad), deputy conservator of forests, Trinidad; J. H. Bowen (senior inspector of plants and produce, Gold Coast), chief inspector of plants and produce, Gold Coast; A. H. Fetherstonhaugh (control officer, Game Department, Federation of Mialaya), chief game warden, Federation of Mialaya; T. P. Lecky (agricultural officer, grade 2, Jamaica), senior livestock officer, Jamaica; W. G. Stuart (agricultural officer, grade 2, Jamaica), agricultural officer, grade 1, Jamaica; C. Teesdale (entomological field officer, Kenya), entomologist, Kenya.

\section{Telecommunications at the Imperial College}

Standard Telephones and Cables, Ltd., have endowed a readership, to be known as the Henry Mark Pease readership in telecommunications, in the City and Guilds College of the Imperial College of Science and Technology, London. Henry Mark Pease, one of the pioneers of the telephone industry in Britain, who died in March 1947, was managing director of Standard Telephones and Cables, Ltd., until 1928; he took an active part in forming the British Broadcasting Company, of which he was one of the original directors. Mr. E. C. Cherry has been appointed to the new readership. Mr. Cherry was attached to the Telecommunication Research Establishment of the Miinistry of Aircraft Production during the war period and is known particularly for his contributions to the subject of electric circuit analysis.

\section{The British Society for International Under- standing}

Sir Arthur Hall has been elected chairman of the British Sbciety for International Understanding in succession to Mr. G. M. Young, the historian and literary critic, who has retired after holding the chairmanship since the Society's incorporation ten years agf. Sir Arthur Hall is director of studies at the Royal Naval College, Greenwich, and is also chairman of the English Association. Mr. Young remains chairman of the Editorial Committee of the Society's publication, The British Survey. Mr. Oliver Bell has been succeeded as vice-chairman of the Society by Colonel John Grace, of British Columbia, formerly director of education of the Canadian Army in Britain during the War.

\section{Linnean Society of London: Officers for 1949}

THE following have been elected officers of the Linneap Society of London for the session 1949-50: Presjent, Prof. F. E. Fritsch; Treasurer, Colonel F. C. Stern; Secretaries, Dr. B. Barnes (botany) and Dr. A. Tindell Hopwood (zoology); New Members of Council, Prof. A. J. E. Cave, Dr. E. B. Ford, C. C. Hentschel and Dr. C. F. A. Pantin.

\section{Announcements}

Mir. Gaoffrey Munday, of the South-West Essex Techpreal College, who has been carrying out research on the temperature variation of the optical properties of gold, has been appointed a research-associate at the Massachusetts Institute of Technology.

A Summer School IN X-Ray Analysis, somewhat simila to those held in Manchester and Cambridge in previous years, is to be held in Leeds during the period August 29-September 10. Further information can be obtained from Prof. E. G. Cox, Department of Inorganic and Physical Chemistry, University, Leeds 2.

THE French Association for the Advancement of Sciences will hold its sixty-eighth annual congress a Clermont-Ferrand, during July 15-21.

Erratum. In a footnote to the communication entitled "Inelastic Scattering of Protons by Mag. nosium and Aluminium" in Nature of May 28, p. 848, the present address of the author, E. H. Rhoderick, is wrongly stated; it should be Department of Natural Philosophy, University of Glasgow. 